\title{
Dissimilarity of parameterized maps generated in geostatistics and the assumption of an automatic software model in precision agriculture
}

\section{Dissimilaridade de mapas gerados na geoestatística parametrizada e seu pressuposto modelo automático de software na agricultura de precisão}

\author{
Katiaíres Evangelista Delpin Malvezi ${ }^{1 *}$; Rubson Natal Ribeiro Sibaldelli; \\ Osvaldo Coelho Pereira Neto ${ }^{3}$; Larissa Alexandra Cardoso Moraes ${ }^{4}$; \\ Otávio Jorge Grigoli Abi Saab ${ }^{5}$; Adônis Moreira ${ }^{4}$
}

\section{Highlights:}

The nonuse of geostatistics in the determination of spatial variability of soil chemical attributes may underestimate or overestimate fertilizer application.

Phosphorus and magnesium show low similarity in maps generated in geostatistics and automatic software.

Dolomite limestone and potassium can be applied without the geostatistics.

\begin{abstract}
Geostatistics is the main technique used to efficiently determine spatial variability. The objective of this study was to evaluate the applicability of the principles of geostatistics in the use of semivariograms elaborated through parametric monitoring and the assumption automatically made by software in the map preparation of soil chemical attributes. Available phosphorus $(\mathrm{P})$, potassium $\left(\mathrm{K}^{+}\right)$, calcium $\left(\mathrm{Ca}^{2+}\right)$, magnesium $\left(\mathrm{Mg}^{2+}\right)$, base saturation $(\mathrm{V} \%)$, sulfur $\left(\mathrm{SO}_{4}{ }^{2-}\right)$, and $\mathrm{pH}$ were compared from the soil chemical attributes of 60 samples of a Typical Oxisol collected at a 0-20 cm depth and a distance of $300 \mathrm{~m}$ between the points. The maps were compared using error matrices and evaluated by the Global Accuracy $(G A)$, Kappa $(K)$, and Tau $(T)$ indexes. The parameterized semivariograms and the automatic software model assumption did not present a high coincidence for the available $\mathrm{P}$ and $\mathrm{Mg}^{2+}$, making it necessary to adjust the semivariogram variables in the spatial analysis as a function of the outliers, sum of squares of residuals, coefficient of determination, and cross-validation to better represent the variability of the data and thus avoid distortions of the sample point range that would affect the adequate representativeness of the attributes, which contrasts with the automatic model generated by the software.
\end{abstract}

Key words: Spatial analysis. Soil chemical attributes. Maps. Semivariogram.

\footnotetext{
Discente do Curso de Doutorado do Programa de Pós-Graduação em Agronomia, Universidade Estadual de Londrina, UEL, Londrina, PR, Brasil. E-mail: kmalvezi@gmail.com

2 Matemático, Especialista em Estatística, Empresa Brasileira de Pesquisa Agropecuária, EMBRAPA Soja, Londrina, PR, Brasil. E-mail: rubson.natal@gmail

3 Prof. Dr., Departamento de Geociências, Centro de Ciências Exatas, UEL, Londrina, PR, Brasil. E-mail: coelho@uel.br

4 Pesquisadores, Empresa Brasileira de Pesquisa Agropecuária, EMBRAPA Soja, Londrina, PR, Brasil. E-mail: larissa.moraes@, embrapa.br; adonis.moreira@embrapa.br

5 Prof. Dr., Departamento de Agronomia, Centro de Ciências Agrárias, UEL, Londrina, PR, Brasil. E-mail: abisaab@uel.br

* Author for correspondence
} 


\title{
Resumo
}

\begin{abstract}
A geoestatística é uma das principais técnicas utilizadas para determinar a variabilidade espacial dos atributos do solo. O objetivo deste trabalho foi comparar o uso de semivariogramas elaborados através do acompanhamento paramétrico da geoestatística e seu pressuposto modelo realizado automaticamente por software na confecção dos mapas de fertilidade do solo. Foram comparados os mapas dos valores de $\mathrm{pH}$, fósforo $(\mathrm{P})$, potássio $\left(\mathrm{K}^{+}\right)$, cálcio $\left(\mathrm{Ca}^{2+}\right)$, magnésio $\left(\mathrm{Mg}^{2+}\right)$, enxofre $\left(\mathrm{SO}_{4}^{2-}\right)$ e saturação por bases (V\%), provenientes de 60 amostras coletadas de área de Latossolo Vermelho Distrófico coletadas na profundidade $0-20 \mathrm{~cm}$ e malha de $300 \mathrm{~m}$ de distância entre os pontos. Os mapas foram comparados por matrizes de erro e avaliadas pelos índices Exatidão Global, Kappa e Tau. O uso de semivariogramas parametrizados e seu pressuposto modelo automático do software não apresentaram alta coincidência para os teores de $\mathrm{P}$ disponível e $\mathrm{Mg}^{2+}$, sendo necessário ajustes das variáveis dos semivariogramas na análise espacial em função dos outliers, soma dos quadrados dos resíduos, coeficiente de determinação e validação cruzada para melhor representação da variabilidade dos dados e assim, evitar distorções do alcance do ponto amostral para uma boa representatividade dos atributos estudados, o que contraria o modelo automático gerado pelo software.
\end{abstract}

Palavras-chave: Análise espacial. Atributos químicos do solo. Mapas de isolinhas. Semivariograma.

\section{Introduction}

The transformations of production processes in the agricultural sector are due to technological innovations generated throughout history (J. E. R. Vieira, 2014). The use of agricultural management systems supported by the spatial and temporal variability of data with the use of precision agriculture aims to optimize profitability and minimize environmental impacts (Tschiedel \& Ferreira, 2002; Costa, Carvalho, Dal Bem, Dalchiavom, \& Caldas, 2014). The application of this technology is necessary; above all, in the study of the chemical, physical, and biological qualities of the soil and its interactions with productive capacity (i.e., the knowledge of the variability of these factors that act in productive systems) is considered the basic principle for the proper management of agricultural areas (Sibaldelli, Carvalho, \& Oliveira, 2015).

Among the technologies adopted, the use of the soil chemical attributes maps presented by geostatistics in precision agriculture allows the variability of areas to be verified (Sibaldelli et al., 2015; Ferreira, Sibaldelli, Morais, Saab, \& Farias, 2017). This allows the producer to adopt corrective measures according to the specific needs of each crop and not at the fixed rates that have been conventionally applied by most producers (Bernardi, Naime, Resende, \& Bassoi, 2014). The proper application of this technique entails better spatial structuring of the variables through an adequate range of sampling points and spatial and temporal distributions (Yamamoto \& Landim, 2013; Silveira \& Moreira, 2016).

However, the association of spatial data analysis and statistical techniques requires elucidating to ensure that there is quality in the interpretation of the information presented and, consequently, practical applicability (Almeida \& Guimarães, 2017). Surveys conducted by Silvestre (2016) and Almeida and Guimarães (2017) demonstrated that despite the significant increase in the interpolation of spatial data, most producers do not use classical geostatistics to define the range of the sampled point. Rather, programs adjust the interpolations by kriging according to semivariograms, with the assumption that the effect is linear.

Even the latest versions of specific software for map-making or georeferenced information systems present modules with geostatistical methods (Yamamoto \& Landim, 2013). The automatic processes embedded in the algorithms and the 
methodologies implemented do not allow the user to intervene if necessary, which may generate inaccuracies that will reflect the significance of the range of the sampling point for interpolation in the field. According to Almeida and Guimarães (2017), the map generated by the default setting of the program compared to those adjusted following the precepts of geostatistics are dissimilar. This misstep may be precisely associated with the particularities of the data and adjustments to the models that need to be analyzed.

The objectives of this study were to: (i) compare the use of semivariograms and their mathematical assumptions performed with software in the preparation of soil fertility maps; and (ii) evaluate the differences in the range of sampling points of the isoline maps of soil chemical attributes generated by a software and those from consolidated geostatistical analyses.

\section{Materials and Methods}

The study area corresponded to a no-till system consolidated (15-year-old) under rainfed conditions in soybean-wheat cropping system located in the Luiziana County, Paraná State, Brazil (16 $15^{\circ} 10^{\prime \prime}$ LS and $47^{\circ} 57^{\prime}$ LO). Sixty georeferenced samples of a Typical Oxisol (Latossolo Vermelho Distrófico, Brazilian classification) with $650 \mathrm{~g} \mathrm{~kg}^{-1}$ of clay were collected at a depth of $0-20 \mathrm{~cm}$, with $300 \mathrm{~m}$ between the points.

After soil collection, the samples were air dried and taken to the laboratory to determine the following chemical attributes (Empresa Brasileira de Pesquisa Agropecuária [EMBRAPA], 1997): $\mathrm{pH}$ in $\mathrm{CaCl}_{2}$, available phosphorus (P) (Mehlich 1), exchangeable potassium $\left(\mathrm{K}^{+}\right)$, exchangeable calcium $\left(\mathrm{Ca}^{2+}\right)$, exchangeable magnesium $\left(\mathrm{Mg}^{2+}\right)$, base saturation (V\%), and available sulfur $\left(\mathrm{SO}_{4}^{2-}\right)$. The history of the area is characterized by the dolomitic limestone application with $13 \%$ magnesium oxide $(\mathrm{MgO})$, gypsum $\left(\mathrm{CaSO}_{4} \cdot 2 \mathrm{H}_{2} \mathrm{O}\right)$, and potassium chloride $\left(\mathrm{KCl}, 60 \% \mathrm{~K}_{2} \mathrm{O}\right)$ in broadcast, while in the band application at sowing, $\mathrm{P}$ [as monoammonium phosphate (MAP), 48\% $\mathrm{P}_{2} \mathrm{O}_{5}$ ] was applied for soybeans (Glycine max [L.] Merrill) and nitrogen, $\mathrm{N}$ (as urea, $45 \% \mathrm{~N}$ ) was applied for wheat (Triticum aestivum L.) according to the recommendations of Moreira et al. (2019).

For comparison purposes, outliers were analyzed within the dataset of each attribute by means of boxplot graphs (Freitas et al., 2008) and were removed when their removal resulted in a better adjustment of the semivariograms. Therefore, to prevent the model from being underestimated or overestimated, a trend of the data based on the significant dispersion plots and correlation coefficients was analyzed and outliers were withdrawn after verification, as suggested by S. R. Vieira, Hatfield, Nielsen and Biggar (1983) who worked with the semivariogram of the residue.

The software GS+ 7.0 - Gamma Design Software [GS+] (2007) allowed the exploratory analysis of the data by determining the classical statistics parameters with skewness, kurtosis, maximum and minimum values, means, standard deviations, and coefficient of variations after the application of the Kolmogorov-Smirnov test to verify the normal distribution of the data.

To test the spatial variability, spherical, Gaussian, exponential, and linear semivariogram models were tested, with the best adjustment of semivariances attributed based on cross-validation, a higher coefficient of determination, and the lowest sum of residue sums. From the theoretical model of the semivariogram, the derived parameters were the nugget effect, $\mathrm{C}_{0}$, sill, $\mathrm{C}_{0}+\mathrm{C}_{1}$, and range, a.

For the spatially dependent variables, isoline maps were generated for interpolation by kriging according to the semivariograms, derived from the function of the parameters of the adjusted model and with minimal deviations from the known values (Grego \& Vieira, 2005). The use of kriging as an interpolator weights the neighbors of the point to be estimated by obeying the minimum variance 
and non-bias (S. R. Vieira, 2000), and allows the control of a portion of the random error, resulting in better estimates (Junqueira, Silva, Mello, \& Pinto, 2008). The maps were also generated using GS+7.0 - Gamma Design Software [GS+] (2007).

For the variables that did not present spatial dependence, the interpolation method used was the inverse of the distance square (Ribeiro, Viola, Demetrio, Manly, \& Fernandes, 2009). According to Viola, Mello, Pinto, Mello and Ávila (2010), this interpolator estimates the variable throughout the space by weighting weights at each of the closest ' $n$ ' posts. The comparative evaluation of the maps generated by the software and those elaborated according to the geostatistical precepts was performed by the Spring ${ }^{\circledR}$ software. This allowed the measurement of the accuracy of the images by error matrices, as evaluated from three indices of mapping accuracy: Global Accuracy (GA), Kappa $(K)$ and Tau $(T)$, which showed in percentages the similarity between the maps.

\section{Results and Discussion}

The maps showed differences when compared to the geostatistical precepts (Figures 1 and $2)$. In the data analysis, it was found that the values of $\mathrm{pH}, \mathrm{Ca}^{2+}, \mathrm{Mg}^{2+}, \mathrm{K}^{+}, \mathrm{V} \%$, and $\mathrm{SO}_{4}^{-2}$ had strong spatial dependence according to the classification of Cambardella et al. (1994), with structured semivariograms ranging from spherical, exponential, linear, and Gaussian models (Figure 3 ), while available $\mathrm{P}$ showed a pure nugget effect (Table 1) given by the random distribution described in detail by Yamamoto and Landim (2013). Possibly this occurrence with available $\mathrm{P}$ was due to microvariability, that is, the spatial variability was lower than that established by the spacing of the samples and therefore not detected by the sampling mesh (Cambardella et al., 1994; Webster \& Oliver, 2007), or was even due to the low mobility and concentration of this element in the soil.

\section{Table 1}

Estimates of the parameters of the semivariograms adjusted to the chemical attributes of a Typical Oxisol at a 0-20 cm depth in areas under a no-till system

\begin{tabular}{ccccccc}
\hline Chemical attribute & $\mathrm{C}_{0}^{(1)}$ & $\mathrm{C}_{1}+\mathrm{C}_{0}^{(2)}$ & $\mathrm{A}^{(3)}(\mathrm{m})$ & Model & $\mathrm{RD}^{(4)}(\%)$ & $\begin{array}{c}\text { Dependency } \\
\text { classification }\end{array}$ \\
\hline $\mathrm{Ca}, \mathrm{cmol}_{\mathrm{c}} \mathrm{dm}^{-3}$ & 0.0085 & 0.056 & 571 & Spherical & 15 & Strong \\
$\mathrm{Mg}, \mathrm{cmol}_{\mathrm{c}} \mathrm{dm}^{-3}$ & 0.0148 & 0.067 & 632 & Linear & 22 & Strong \\
$\mathrm{K}, \mathrm{cmol}_{\mathrm{c}} \mathrm{dm}^{-3}$ & 0.0005 & 0.088 & 560 & Spherical & 0 & Strong \\
$\mathrm{P}, \mathrm{mg} \mathrm{dm}^{-3}$ & 0.0101 & 0.010 & - & PNE & - & - \\
$\mathrm{S}^{(5)} \mathrm{SO}_{4}^{2-}, \mathrm{mg} \mathrm{dm}^{-3}$ & 0.0013 & 0.019 & 276 & Exponential & 7 & Strong \\
$\mathrm{pH}, \mathrm{CaCl}_{2}$ & 96.000 & 54.300 & 561 & Gausian & 18 & Strong \\
$\mathrm{V}, \%$ & 0.2000 & 111.600 & 592 & Spherical & 0 & Strong \\
\hline
\end{tabular}

${ }^{(1)} \mathrm{C}_{0}$ : nugget effect; ${ }^{(2)} \mathrm{C}_{0}+\mathrm{C}_{1}$ : sill; ${ }^{(3)} \mathrm{A}$ : reach; ${ }^{\left({ }^{4}\right)} \mathrm{RD}$ : ratio dependency spatial $(\mathrm{Co} / \mathrm{Co}+\mathrm{C}) \times 100$; ${ }^{(5)} \mathrm{PNE}$ : pure nugget effect.

Despite the variability of the maps, the soil chemical attributes were within the levels considered adequate for soybean cultivation (Moreira, Moraes, Schroth, Becker, \& Mandarino, 2017; Moreira et al., 2019). Except for $\mathrm{S}_{-} \mathrm{SO}_{4}^{2-}$ , with a maximum distance range of $276 \mathrm{~m}$, and the pure nugget effect of available $\mathrm{P}$ (Table 1), the other soil attributes $\left(\mathrm{pH}, \mathrm{Ca}^{2+}, \mathrm{Mg}^{2+}, \mathrm{K}^{+}\right.$, and $\mathrm{V} \%$ ) ranged between $560 \mathrm{~m}$ and $632 \mathrm{~m}$. These low differences are considered as good uniformity of the parameters for the fertilizers application at variable rates because they demonstrate good homogeneity 
in the area, which facilitates the manipulation of agricultural equipment with the application of the same amount of fertilizer. In addition, the distance between the sampled points for these variables was adequate. These results corroborate Souza, Cogo and Vieira (1997) and Sibaldelli et al. (2015), who reported that in the study of the spatial continuity of soil chemical and physical attributes, the main objective of semivariograms is the determination of the appropriate number of samples and their range in terms of the spatial dependence of each sampling point.

Another factor to be considered in the interpretation of the data is the evaluation of the accuracy of the generated maps (Campagnolo \& Caetano, 2002). These authors also reported that it is necessary to evaluate the analysis of the error matrix and the classification index, whose results indicate the degree of variability of the points, which image is considered the most appropriate, and what factors are most used to accurately evaluate the classification of the images generated.

The values of the Global Accuracy (GA), Kappa $(K)$ and Tau $(T)$ indexes were used to measure the accuracy of the classification of images generated (Table 2). Despite the differences between the three determiners, it was possible to observe that the $G A$ index overestimated the results, $T$ index underestimated the results, and $K$ index proved to be an intermediate classifier (Ponzoni \& Rezende, 2002). Congalton (1991) reported that the use of the $K$ index is the most satisfactory in the evaluation of the thematic classification accuracy because it uses all elements of the error matrix, not only the main diagonal.

Table 2

Maps of soil chemical attributes classification, comparing before and after geostatistical technical detailing, through the classifiers Global Accuracy $(G A)$, Kappa $(K)$ and Tau $(T)$

\begin{tabular}{|c|c|c|c|c|c|c|c|}
\hline \multirow{2}{*}{ Classification } & $\mathrm{Ca}^{2+}$ & $\mathrm{Mg}^{2+}$ & $\mathrm{K}^{+}$ & $\mathrm{P}$ & $\mathrm{S}-\mathrm{SO}_{4}^{2-}$ & $\mathrm{pH}$ & V $(\%)$ \\
\hline & \multicolumn{7}{|c|}{ - } \\
\hline GA & 60.1 & 30.4 & 70.5 & 43.4 & 47.8 & 62.6 & 65.2 \\
\hline $\mathrm{T}$ & 53.5 & 18.8 & 65.5 & 34.0 & 39.1 & 56.3 & 59.4 \\
\hline K & 51.4 & 16.5 & 63.1 & 18.5 & 31.4 & 54.7 & 57.7 \\
\hline
\end{tabular}

$\mathrm{V}$, base saturation. $\mathrm{pH}$ in $\mathrm{CaCl}_{2}$.

Potassium, base saturation (V\%), $\mathrm{pH}$, and $\mathrm{Ca}^{2+}$ were the attributes that most closely approached the maps generated using only the linear model and the best fit described in Table 1, with percentages above $50 \%$. Using the $K$ classifier as a parameter (Table 2 ), this coincidence could be confirmed by the similarity between the ranges of the sampling points in the maps, with precisions of $63.1 \%$ for $\mathrm{K}^{+}, 57.7 \%$ for $\mathrm{V} \%, 54.7 \%$ for $\mathrm{pH}$, and $51.4 \%$ for $\mathrm{Ca}^{2+}$ (Figures 1 and 2). On the other hand, the levels of $\mathrm{Mg}^{2+}$, even applied to the pitch in the form of dolomitic limestone $(>13 \mathrm{MgO})$, and available $\mathrm{P}$ showed the lowest similarities, with similarity values of $16.5 \%$ and $18.5 \%$, respectively, while $\mathrm{S}_{-} \mathrm{SO}_{4}{ }^{2-}$ was considered as intermediate (31.4\%) (Table 2). The slightest approximation of the available $\mathrm{P}$ maps can be justified by the pure nugget effect represented by the semivariogram (Table 2 and Figure 3 ). Generally, by default, the software automatically submits the interpolation by kriging even if the variable has not presented spatial dependence, that is, it is an inadequate estimator that generates inconsistent results (Almeida \& Guimarães, 2017). 


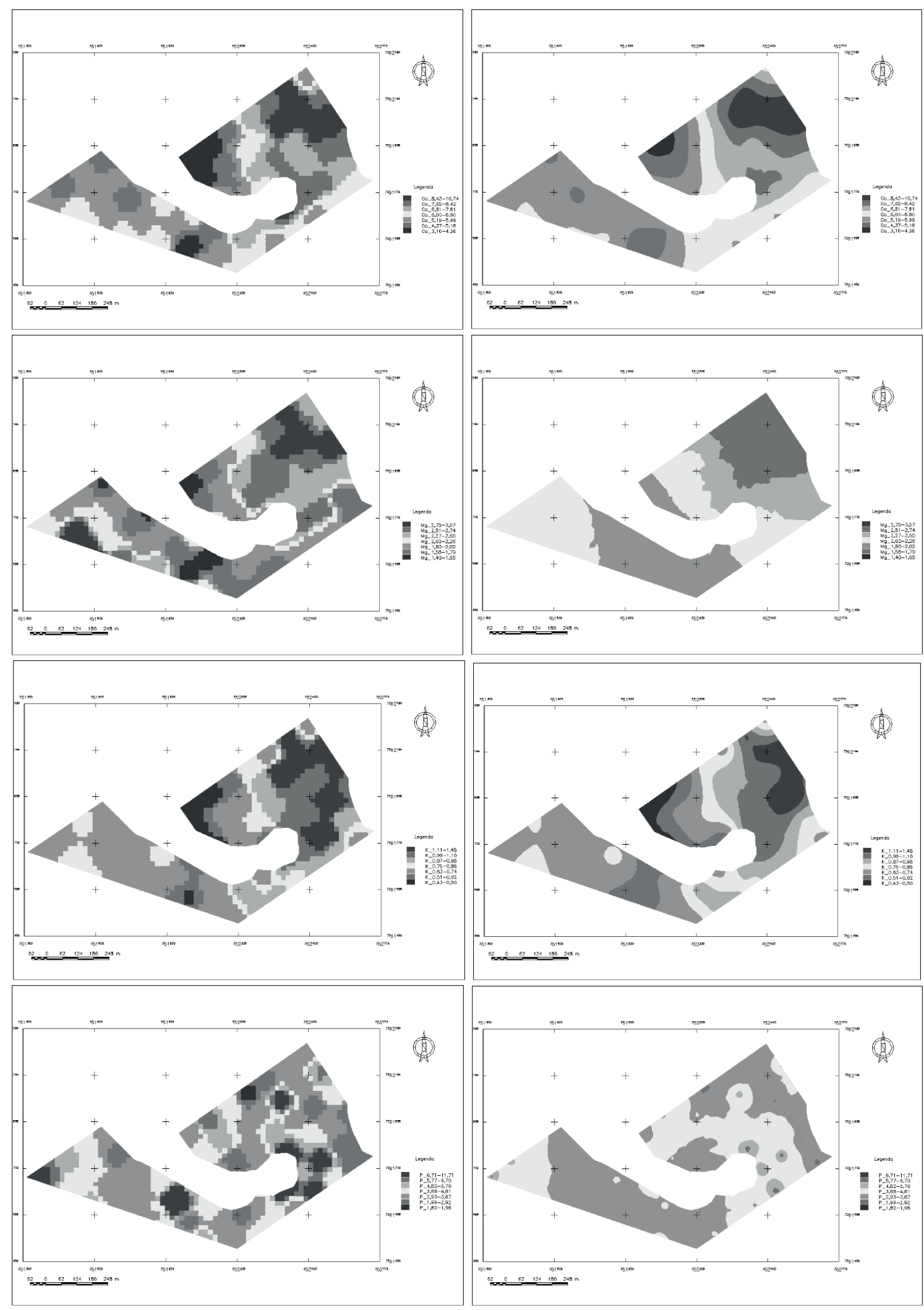

Figure 1. Maps of the calcium $\left(\mathrm{Ca}^{2+}\right)$, magnesium $\left(\mathrm{Mg}^{2+}\right)$, potassium $\left(\mathrm{K}^{+}\right)$and available phosphorus $(\mathrm{P})$ concentrations in a Typical Oxisol at a $0-20 \mathrm{~cm}$ depth generated by the mathematical assumption (left) and by geostatistical technical detailing with the use of the semivariogram (right). 

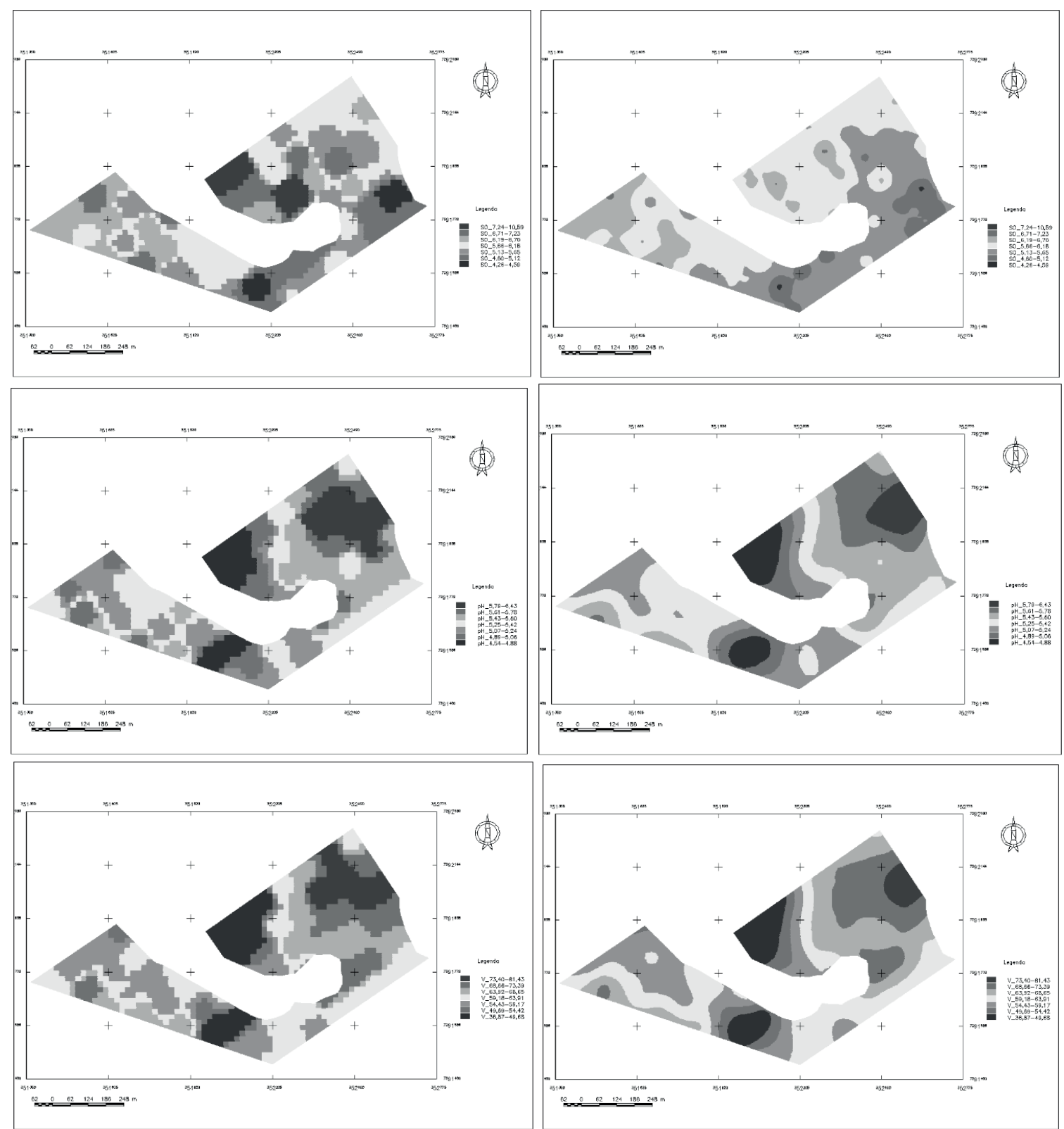

Figure 2. Maps of available sulfur $\left(\mathrm{SO}_{4}^{2-}\right), \mathrm{pH}$ and base saturation (V\%) from a Typical Oxisol at a 0-20 $\mathrm{cm}$ depth generated by the mathematical assumption (left) and by geostatistical technical detailing with the use of the semivariogram (right).

In the case of $\mathrm{Mg}^{2+}$ (Table 1 and Figure 3), the linearity attributed to the semivariogram model did not allow the reach of sill and therefore did not stabilize, as described by Rendu (1978). This fact does not provide the standardization of the maps generated by expressing infinite dispersal capacity, especially in situations where there is no certainty of the technique attributed to the construction of the maps being compared. The exponential semivariogram presented by available $\mathrm{SO}_{4}^{2-}$ (Table 1) was after the removal of four extreme outliers that were very divergent from the mean, and even then the frequency distribution was not favorable for the reach of the sampling point, justifying a random distribution. 
Regardless of the attributes analyzed, the estimation of these statistics after the removal of the outliers caused skewness and better kurtosis, with less flattening of the distribution in relation to the normal curve in the data because there was equivalence between the mean and median sensitivity and also a reduction in the coefficients of variation, which did not occur with the mathematical assumption, this

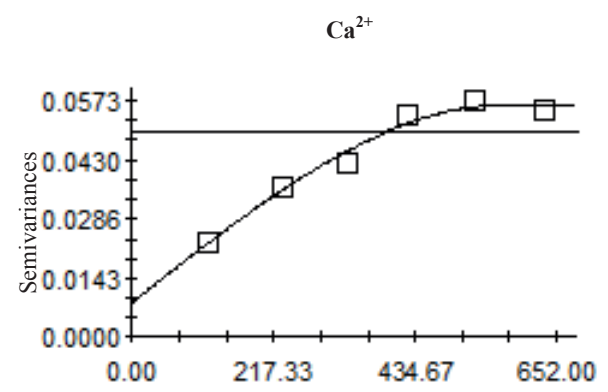

$\mathbf{K}^{+}$

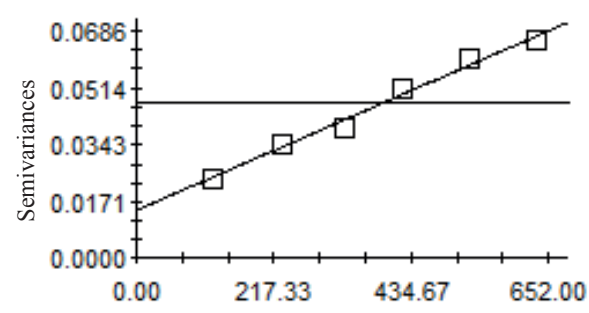

Available $\mathrm{S}_{-} \mathrm{SO}_{4}{ }^{2-}$
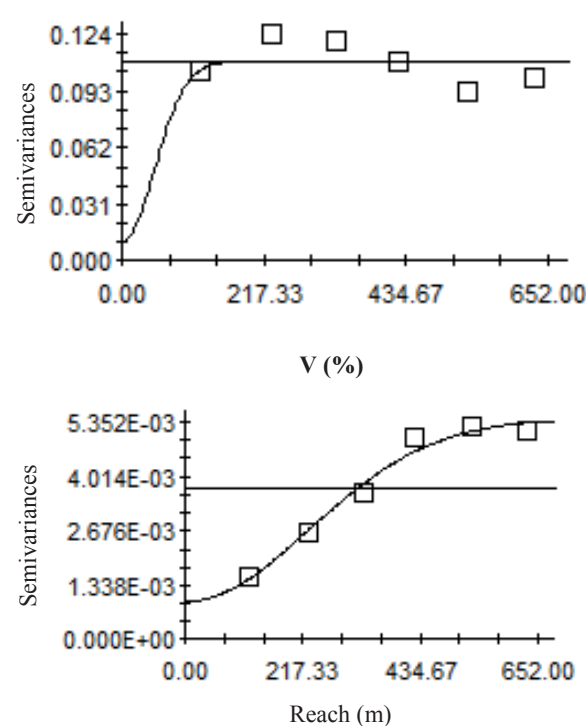

also being another divergence factor justified by the precision index (Table 2) and the maps (Figures 1 and 2). According to Freitas et al. (2008), the skewness and kurtosis of the data are measures that demonstrate the amplitude of the data regarding the distribution of the normal curve, which affects the inferences obtained, the estimation of the fixed effects, and the heterogeneity of the variance of the error.
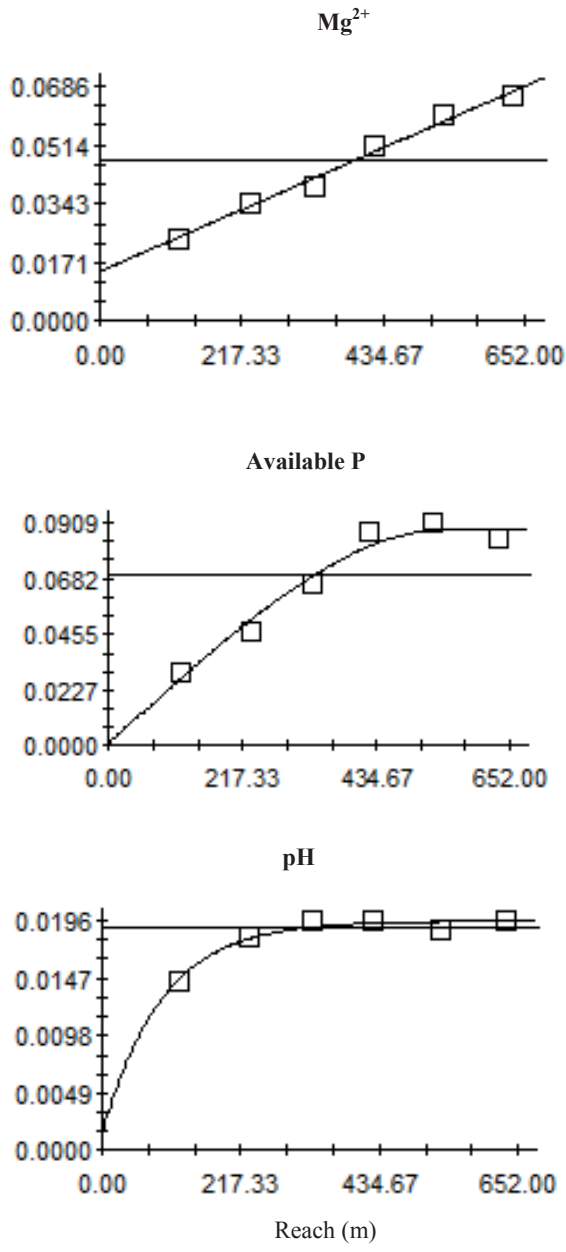

Figure 3. Semivariances of exchange calcium $\left(\mathrm{Ca}^{2+}\right)$, magnesium $\left(\mathrm{Mg}^{2+}\right)$ e potassium $\left(\mathrm{K}^{+}\right)$, available phosphorus $(\mathrm{P})$, available sulfur $\left(\mathrm{S}_{-} \mathrm{SO}_{4}{ }^{2-}\right), \mathrm{pH}$ (calcium chloride, $\mathrm{CaCl}_{2}$ ), and base saturation $(\mathrm{V} \%)$ of a Typical Oxisol at a $0-20 \mathrm{~cm}$ depth by geostatistical technical detailing. 
The absence of the refinement and critical analysis of the data caused interference in the formation of the maps. When the results of the attributes were analyzed with the use of the models of structured semivariograms for the $\mathrm{K}^{+}, \mathrm{V} \%, \mathrm{pH}$, and $\mathrm{Ca}^{2+}$ values, the maps were more similar to the geostatistical attributions (that is, the automatic development of the maps by the software without major limitations causing distortions). This was verified by $\mathrm{Mg}^{2+}, \mathrm{P}$, and $\mathrm{S}_{-} \mathrm{SO}_{4}^{2-}$ (Figures 1 and 2), since the geostatistically generated maps met the mathematical criteria and demonstrated peculiarities that required more specific adjustments and interpretations.

Therefore, the importance of the knowledge and application of geostatistical techniques in a judicious manner is necessary, even with specific software for mapping with intrinsic geostatistical analysis, since the data and variables do not behave uniformly (Bernardi et al., 2014).

\section{Conclusions}

The maps generated by means of the semivariograms of spatial variability and the mathematical assumption with the classifier $\mathrm{K}$ showed that the soil chemical attributes showed similarity for the values of $\mathrm{K}^{+}, \mathrm{V} \%, \mathrm{pH}$, and $\mathrm{Ca}^{2+}$, with percentages above $50 \%$, while the levels of $\mathrm{Mg}^{2+}$ and available $\mathrm{P}$ had the lowest similarities, with similarity values of only $16.5 \%$ and $18.5 \%$, respectively.

The GA index overestimate and $T$ index underestimate, while $K$ index proves to be an intermediate classifier to measure the accuracy of the classification of images generated for the chemical attributes of a Typical Oxisol (Latossolo Vermelho Distrófico).

\section{Acknowledgments}

We thank the Santa Rita laboratory for the georeferenced data for this work and the $\mathrm{CNPq}$
(National Council for Research and Development) for providing a doctoral scholarship to the first author and Research Productivity scholarship to the sixth author.

\section{References}

Almeida, L. S., \& Guimarães, E. C. (2017). Agricultura de precisão: um alerta à imprecisão - estudo de caso na cafeicultura. Revista de Agricultura Neotropical, 4(2), 41-48. doi: 10.32404/rean.v4i2.1469

Bernardi, A. C. C., Naime, J. M., Resende, A. V., \& Bassoi, L. H. (2014). Agricultura de precisão: resultados de um novo olhar. Brasília: EMBRAPA Tecnologia da Informação.

Cambardella, C. A., Moorman, T. B., Novak, J. M., Parkin, T. B., Karlen, D. L., Turco, R. F., \& Konopka, A. E. (1994). Field scale variability of soil properties in Central Iowa soils. Soil Science Society of America Journal, 58(5), 1501-1511. doi: 10.2136/ sssaj1994.03615995005800050033x

Campagnolo, M. L., \& Caetano, M. S. (2002). Abordagens multiestratégicas para classificação de imagens de satélite: aplicação numa zona florestal. Lisboa: (Relatório Técnico, 6). Departamento de Matemática, Instituto Superior de Agronomia, Universidade Técnica de Lisboa.

Congalton, R. G. (1991). A review of assessing the accuracy of classifications of remotely sensed data. Remote Sensing of Environment, 49(12), 1671-1678. doi: 10.1016/0034-4257(91)90048-B

Costa, N. R., Carvalho, M. P., Dal Bem, E. A., Dalchiavom, F. C., \& Caldas, R. R. (2014). Produtividade de laranja correlacionada com atributos químicos do solo visando a zonas específicas de manejo. Pesquisa Agropecuária Tropical, 44(4), 391-398. doi: 10.1590/S1983-40632014000400001

Empresa Brasileira de Pesquisa Agropecuária (1997). Manual de métodos de análise de solo. (2a ed.). Rio de Janeiro: EMBRAPA Solos.

Ferreira, R. C., Sibaldelli, R. N. R., Morais, H., Saab, O. J. G. A., \& Farias, J. R. B. (2017). Spatial variability of meteorological observations and impacts on regional estimates of soybean grain productivity. Semina: Ciências Agrárias, 38(4), 2265-2278. doi: 10.5433/1679- 0359.2017v38n4Sup11 p2265

Freitas, A. R., Barioni, W., Jr., Ferreira, R. P., Cruz, C. D., Moreira, A., \& Vilela D. (2008). Técnicas de análises exploratórias em dados de cultivares de alfafa. 
Revista Brasileira de Zootecnia, 37(9), 1531-1536. doi: 10.1590/S1516-35982008000900003

Gamma Design Software GS+ (2007). Geostatistical for environmental science. Versão 7. Michigan: Gamma Design Software. Citação da referência no texto incompleta. Corrigir para: Gamma Design Software [GS+] (2007).

Grego, C. R., \& Vieira, S. R. (2005). Variabilidade espacial de propriedades físicas do solo em uma parcela experimental. Revista Brasileira de Ciencia do Solo, 29(2), 169-177. doi: 10.1590/S010006832005000200002

Junqueira, J. A., Jr., Silva, A. M., Mello, C. R., \& Pinto, D. B. F. (2008). Continuidade espacial de atributos físico-hídricos do solo em sub-bacia hidrográfica de cabeceira. Ciência e Agrotecnologia, 32(3), 914922. doi: 10.1590/S0100-06832005000200002

Moreira, A., Costa, A., Motta, A. C. V., Muniz, A. S., Cassol, L. C., Zanão, L. A., Jr., \& Pauletti, V. (2019). Manual de adubação e calagem para o Estado do Paraná. Curitiba: SBCS-NEPAR.

Moreira, A., Moraes, L. A. C., Schroth, G., Becker, F. J., \& Mandarino, J. M. G. (2017). Soybean yield and nutritional status response to nitrogen sources and rates of foliar fertilization. Agronomy Journal, 109(2), 629-635. doi: 10.2134/agronj2016.04.0199

Ponzoni, F. J., \& Rezende, A. C. P. (2002). Influência da resolução especial de imagens orbitais na identificação de elementos da paisagem em AltamiraPA. Árvore, 26(4), 403-410. doi: 10.1590/S010067622002000400002

Rendu, J. M. (1978). An introduction to geostatistical methods of mineral evaluation. Johannesburg: South African Institute of Mining and Metallurgy.

Ribeiro, P. J., Jr., Viola, D. N., Demetrio, C. G. B., Manly, B. F., \& Fernandes, O. A. (2009). Spatial pattern detection modeling of thrips (Thrips tabaci) on onion fields. Scientia Agricola, 66(1), 90-99. doi: 10.1590/S0103-90162009000100013

Sibaldelli, R. N. R., Carvalho, J. F. C., \& Oliveira, M. C. N. (2015). Uso de geoestatística no estudo da variabilidade espacial da capacidade de troca de cátions do solo. Global Science Technology, 8(1), 141156. doi: 10.14688/1984-3801/gst.v8n1p141-156
Silveira, R. V. A., \& Moreira, A. (2016). Aplicação de taxa variável uniformiza as áreas e maximiza o uso de fertilizantes e corretivos em floresta de eucalipto e pinus no Estado de Minas Gerais. Addubare, 31(2), 9-9.

Silvestre, M. R. (2016). Técnicas estatísticas utilizadas em climatologia geográfica: diagnóstico $e$ propostas. Tese de doutorado, Faculdade de Ciências e Tecnologia, Universidade Estadual Paulista, Presidente Prudente. São Paulo, Brasil.

Souza, L. S., Cogo, N. P., \& Vieira, S. R. (1997). Variabilidade de propriedades físicas e químicas do solo em pomar cítrico. Revista Brasileira de Ciência do Solo, 21(3), 1-10. doi: 10.1590/S0100-06831997 000300003

Tschiedel, M., \& Ferreira, M. F. (2002). Introdução à agricultura de precisão: conceitos e vantagens. Ciência Rural, 32(1), 159-163. doi: 10.1590/S010384782002000100027.

Vieira, J. E. R., Fo. (2014). Transformação histórica e padrões tecnológicos da agricultura brasileira. In A. M. Buainain, E. Alves, J. M. Silveira, \& Z. Navarro (Ed.), O mundo rural no Brasil do século 21: a formação de um novo padrão agrário e agrícola (pp. 395-452). Brasília: EMBRAPA Tecnologia da Informação.

Vieira, S. R. (2000). Geoestatística em estudos de variabilidade espacial do solo. In R. F. Novais, V. V. H. Alvarez, \& C. E. G. R. Schaefer (Ed.), Tópicos em ciência do solo (pp. 1-54). Viçosa, MG: Sociedade Brasileira de Ciência do Solo.

Vieira, S. R., Hatfield, J. L., Nielsen, D. R., \& Biggar, J. W. (1983). Geostatistical theory and application to variability of some agronomical properties. Hilgardia, 51(1), 1-75. doi: 10.3733/hilg.v51n03p075

Viola, R. M., Mello, C. R., Pinto, D. B. F., Mello, J. M., \& Ávila, L. F. (2010). Métodos de interpolação espacial para o mapeamento da precipitação pluvial. Revista Brasileira de Engenharia Agrícola e Ambiental, 14(9), 970-978. doi: 10.1590/S141543662010000900009

Webster, R., \& Oliver, M. A. (2007). Geostatistics for environmental scientists. Chichester: John Wiley \& Sons.

Yamamoto, J. K., \& Landim, P. M. B. (2013). Geoestatística: conceitos e aplicações. São Paulo: Oficina de Textos. 